\title{
The balancing act: A qualitative study on remote work and childcare during the COVID-19 lockdown in South Africa
} [version 1; peer review: 1 approved with reservations]

\author{
Salome Scholtz
}

WorkWell Research Unit, North West University, Potchefstroom, North West, 2520, South Africa

V1 First published: 16 Jun 2021, 10:481

https://doi.org/10.12688/f1000research.53579.1

Latest published: 16 Jun 2021, 10:481

https://doi.org/10.12688/f1000research.53579.1

\section{Abstract}

Background: The coronavirus disease 2019 (COVID-19) pandemic has impacted many employees' world by forcing some to remote work whilst also caring for children.

Methods: This study explored the remote working experiences of child caregivers in balancing work and childcare during the South African COVID-19 lockdown period (from 26 March 2020 to 31 December 2020). A qualitative descriptive design was employed to collect data through an online qualitative questionnaire with semistructured questions. A final sample of 22 participants was included using purposive and snowball sampling.

Results: Findings indicate that employees experienced difficulty balancing work and childcare, which prompted them to use personal and organisational resources to restore work-life balance. These resources included people, spaces and time.

Conclusions: This study provides insight for employers and healthcare workers into how remote workers balanced work and childcare and can promote conversations or interventions on improving employee remote work experiences - especially in the unique South African context.

Keywords

Caregiving, COVID-19, lockdown, remote work, work-life-balance, work experiences, working from home.

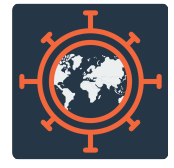

This article is included in the Emerging Diseases and Outbreaks gateway.

\section{Open Peer Review \\ Approval Status ? \\ 1 \\ version 1 \\ $?$ \\ 16 Jun 2021 \\ view}

1. Auditya Purwandini Sutarto (D), Universitas Qomaruddin Fakultas Teknik, Gresik, Indonesia

Any reports and responses or comments on the article can be found at the end of the article. 
This article is included in the Coronavirus

collection.

Corresponding author: Salome Scholtz (salomescholtz01@gmail.com)

Author roles: Scholtz S: Conceptualization, Data Curation, Formal Analysis, Investigation, Methodology, Project Administration, Resources, Supervision, Visualization, Writing - Original Draft Preparation, Writing - Review \& Editing

Competing interests: No competing interests were disclosed.

Grant information: The author(s) declared that no grants were involved in supporting this work.

Copyright: (c) 2021 Scholtz S. This is an open access article distributed under the terms of the Creative Commons Attribution License, which permits unrestricted use, distribution, and reproduction in any medium, provided the original work is properly cited.

How to cite this article: Scholtz S. The balancing act: A qualitative study on remote work and childcare during the COVID-19 lockdown in South Africa [version 1; peer review: 1 approved with reservations] F1000Research 2021, 10:481

https://doi.org/10.12688/f1000research.53579.1

First published: 16 Jun 2021, 10:481 https://doi.org/10.12688/f1000research.53579.1 


\section{Introduction}

The novel coronavirus disease 2019 (COVID-19) is an infectious viral disease that has shaken the world of work through a COVID-19-all-remote work experiment (Liang, 2020; Tavares, 2017). This experiment resulted in specific sectors' employees using their homes as workplaces, relaxation spaces and schools for the first time (Oakman et al., 2020). According to the Organisation for Economic Cooperation and Development (OECD) (OECD, 2020), work productivity has declined on individual and organisational levels due to the lack of childcare support, violations of family-work boundaries and social isolation. South Africa has the highest number of COVID-19 infections on the African continent (Mwai, 2020; South African Corona Virus portal, 2021). Additionally, the population is under a unique threat during the pandemic with its high HIV and tuberculosis infections, diabetes and shared substance abuse (Egbe et al., 2019; Egbe \& Ngobese, 2020).

After the first positive COVID-19 case was reported in South Africa on March 5, 2020 (Stiegler \& Bouchard, 2020), the infection rate quickly increased and lead to drastic measures taken by the South African government, namely: a nationwide lockdown starting on March 26, 2020 (South African Government News Agency, 2020). According to The Human Sciences Research Council (HSRC) (2020), the middle class South African citizens adhered to the lockdown regulations well; staying home and working remotely, which according to Putro and Riyanto (2020), is a highly desired work arrangement for this professional group. However, as in-person schools and childcare centres were closed during some phases of the lockdown, childcare responsibilities increased, thereby blurring the boundaries between work and home (Shockley et al., 2020). This study sought to explore the experiences of these South African employees in balancing remote work and childcare during the 2020 South African lockdown to identify opportunities where managers and healthcare workers can lend support to these employees.

Lockdown is a situation where people are not allowed free movement in an area due to danger, such as that posed by the COVID-19 pandemic. The South African lockdown started on level five, the strictest lockdown level, indicating a high COVID-19 infection rate and low health system readiness (Businesstech, 2020). The lockdown was soon extended, and the country only entered lockdown level one on September 20, 2020 (Mwai, 2020; Stiegler \& Bouchard, 2020). During the level five lockdown, all activities such as dog-walking, attending school, outdoor exercises, the use or purchase of alcohol and cigarettes (public consumption) were banned (Stiegler \& Bouchard, 2020), making South Africa one of the African countries with the strictest lockdown regulations (Stiegler \& Bouchard, 2020). The restrictions slowly eased with every level after that, with lockdown level three (May 31), for example, allowing alcohol retailing, religious activities and exercise (South African Coronavirus Portal, 2020a).

During the lockdown, certain employees found themselves remote working for the first time by conducting work at home or a place other than that of the organisation's usual site (Baruch, 2000; Cambridge Dictionary, 2021). This work arrangement can potentially promote various personal and professional benefits, for example, a better work-life balance for employees (Sarbu, 2020), improved company culture, communication and productivity (Tuyo, 2020). Baard and Thomas (2010) found that South Africans experienced improved organisation loyalty, productivity and work-life balance when working from home. Choudhury (2020) adds that remote workers enjoy the freedom to work from home and experience a higher quality of life, improving their overall happiness. Organisations also benefit by increasing employee engagement with happier and more productive employees and lower office hire expenses. However, Anderson and Kelliher (2020) warn that remote work benefits differ when enforced and full-time. Their research indicates that the benefit of autonomy and gratitude employees experience from willingly remote working can be lower when employees are deprived from the choice to do so. This lowered remote work benefit can especially be seen in mothers due to less control of when and how work is conducted in the midst of family responsibilities when employees are forced to work from home (Anderson \& Kelliher, 2020).

First-time remote workers in South Africa experienced work overload and performance pressure despite the positive aspects of working remotely (Matli, 2020). This work overload was especially true when employees' home responsibilities increased, and work-life boundaries became vague (Sarbu, 2020). Due to the governmental lockdown, parents had to work from home while fulfilling their children's teacher and parent roles (Casale \& Posel, 2020). Thus, a tremendous burden was placed on families (Del Boca et al., 2020) as they balanced their responsibilities in unexpected ways (Limoncelli, 2020) and work hours were influenced by what happened within homes (Casale \& Posel, 2020). In academia, for example, some researchers have experienced a decrease in publications during the lockdown, which could be due to juggling childcare and working from home (Hedding et al., 2020). Research shows that one parent's need to stay home and care for the children has made it difficult, especially for women, to work during the COVID-19 pandemic (Queisser et al., 2020). According to Odek (2020), the school closures restricted South African women as many women had to stay home and care for children instead of working (Odeku, 2020). 
South African child caregivers fulfilled these roles of parent, teacher, and employee until August 3 2020, when schools gradually opened, starting with Grade 12 learners (Enca, 2020). The largest group of learners, grades R to four, six, nine, 10 and 11, started attending school on August 24, and the final grades five and eight returned on the 31st (Makou, 2020). However, as most schools could not fulfil the requirements for social distancing in 2021, half of the learners still spend some time at home during the week. Some schools accept learners on a 'week on' - 'week off' basis, and other schools allow learners to attend school every second day. This type of arrangement led to learners attending half the school days of the second part of the school year in 2020 (van der Berg, 2020). Working from home was also complicated by childcare as it interfered with conducting remote work, as some employees feared clients might infect their children if they met at home (Odeku, 2020). Adding to this was caring for those who have contracted the COVID-19 virus and expanding work hours (Khwela-Mdluli \& Beharry-Ramraj, 2020). Therefore, Khwela-Mdluli and Beharry-Ramraj (2020) and Odeku (2020) urged South Africa to devise systems to support the health and work equality of South African remote working women. This system is especially imperative during school closures and women carrying the burden of care and remote work for their families (Odeku, 2020).

International research also shows that most of the additional work during lockdown fell on women (Sevilla \& Smith, 2020). A Spanish study found that women experienced higher work and family conflict than men (Lopez-Núčez et al., 2021). In contrast, Del Boca et al. (2020) indicated that childcare was distributed equally between Italian parents whilst home activities were still primarily the responsibility of women. Time spent with children during the lockdown was also less if the parents returned to workplaces after the lockdown (Del Boca et al., 2020). Research by Shockley et al. (2020) investigated the gender roles whilst remote working and caring for children. Their results showed that dual-earner couples assumed gendered roles during the lockdown. In contrast, men only occasionally looked after children (e.g. when wives were in meetings or one day a week), with most or all childcare duties falling on wives. They also found women had high relationship tension, low family cohesion and poor job performance. Men also experienced some impact on job performance, presumably due to marital strife due to unequal distribution of household duties (Shockley et al., 2020).

Additionally, couples tried alternating days of work and care with one partner working in the morning and the other in the evening; this, however, still impacted their job performance and may not help those who work remotely full-time (Shockley et al., 2020). In India, women experienced higher emotional exhaustion than men caused by personal life interference whilst working from home (Bhumika, 2020). Putro and Riyanto (2020), on the other hand, found that Asian sandwich generations, i.e. persons caring for both their parents and their children, experienced relief from work conflict as their parents could assist in childcare while they remote worked. South African households, however, are unique compared to international families due to parental absence (Hall, 2019). According to Hall (2019), South African children make up 34\% (19.7 million) of the total South African population, and of these children, only $34 \%$ live with both their biological parents (Hall, 2019; Hall \& Mokomane, 2018). Thus, children are often raised by relatives, without fathers or live separate from their siblings (Hall, 2019).

\section{Management and remote work during COVID-19 lockdown}

The COVID-19 pandemic has left many businesses in turmoil and managers losing sleep over their employees' struggles (Zaki, 2020). At the onset of the COVID-19 pandemic, UNICEF encouraged employers to provide time and support to new remote working parents through, for example, reassessing workplace policies, flexible work time, good hygiene at workplaces and giving assistance to cope with stress (UNICEF, 2020). Despite the opening of schools and childcare centres, Watson (2020) warns human resource (HR) workers should not think that all children have returned to school. With the COVID-19 outbreak seen as continuous (Jones, 2020) and the unpreparedness and weak infrastructure of South African schools, many parents cannot or do not send their children to school full-time or at all (Amnesty International, 2021). This is further supported by South African homeschooling agencies such as Impaq that have experienced a rise in homeschool applications to 5000 more learners in August of 2020 (Businesstech, 2020). Many parents have adopted this learning mode as their new permanent schooling option after the national lockdown (Businesstech, 2020). To combat this change in work-life, some international HR firms have engaged in conversations with their employees and encouraged larger organisations to conduct surveys to gain insight into employee experiences in August 2020 (Watson, 2020). Croce (2020) encourages communication from organisation leaders, specifically regarding showing empathy to employees' experiences as an effective way to minimise the anxiety and consequences of COVID-19 in the workplace. The benefits of these types of inquiries can be seen in industries such as the automotive industry, where more managers have grown comfortable with flexible work schedules and arrangements, especially for employees with children, following the pandemic (Muller \& Burden, 2020).

Remote work holds various benefits for employees, such as the opportunity to arrange their work schedule to reconcile their work-family conflict, especially for those employees who also fulfil caregiving roles (Sarbu, 2018). However, COVID-19 has forced many employees to work from home under the worst conditions (Bloom, 2020). Bloom (2020) 
states that no employee should be forced to work from home due to variation in employees' desire to do so and their different home environments. Choudhury (2020) and Bloom (2020) therefore encourage knowledge workers to take the time and attention to overcome the potential hurdles to remote work during the COVID-19 lockdown in order to continue remote working and reap its benefits post COVID-19. This attention is imperative, as working at home may become the norm for many employees in the foreseeable future (Oakman, 2020), and is becoming a reality for South Africa as it experiences a flux in infections (South African Coronavirus Portal, 2020). Therefore, it may be prudent to investigate the experiences and possible strategies caregivers have employed during the first lockdown to determine the role an organisation and healthcare workers can play in improving remote work whilst caregiving. Thus, the research question will be: What is the remote working experiences of child caregivers in balancing work and childcare during the South African COVID-19 lockdown period?

This article adds knowledge to research with regards to how South African employees managed remote work and child caregiving during the COVID-19 pandemic. Findings may allow managers and organisations insight into the homework lives of caregivers and possibly promote conversations and interventions on how they can assist these employees in remote working. Helping remote workers will ease the burden on employees and this study is especially imperative as South African households can differ vastly from international homes (Hall, 2019), making South African employee experiences unique. This study will also contribute to knowledge about the qualitative descriptive research design, a valid research method in need of methodological transparency in literature (Doyle et al., 2020). Additionally, this study utilised an online questionnaire that is not often used for this type of design (Kim et al., 2017) and may provide support for online questionnaires as data collection methods in these times of social distancing.

\section{Research purpose and research question}

This study's general aim is to explore the shared lived experiences of South African employees with regards to how they conducted or balanced their work whilst fulfilling caregiver roles during the COVID-19 lockdown. Based on the posed research question and aim, the following specific objectives were explored:

- Who were the role players that promoted or hindered balancing remote work and childcare during the COVID-19 lockdown?

- What organisational or personal resources have employees used in balancing their remote work and childcare during the COVID-19 lockdown?

- What role could organisations play in assisting employees with balancing remote work and childcare?

\section{Methods}

A qualitative research method was followed in this study. Therefore, the researcher focused on how participants organise themselves in their contexts and make sense of these contexts through naturalistic research using words (Nieuwenhuis, 2016a).

\section{Qualitative approach and research paradigm}

This study was conducted through a qualitative descriptive research design. Qualitative descriptive designs aim to create straightforward descriptions of participants' experiences (Sandelowski, 2010) and are not focused or committed to a theoretical analysis of data (Doyle et al., 2020) or increasing conceptual understanding (Chafe, 2017). According to Bradshaw et al. (2017), this design presents data in terminology closely related to the research question whilst recognising the participant experiences' subjective nature. Thereby determining the who, what and where of a phenomenon (Sandelowski, 2000) and providing information that can easily be used for future interventions (Neergaard et al., 2009; Sullivan-Bolyai et al., 2005). The philosophical underpinning of the qualitative descriptive design is pragmatism (Neergaard et al., 2009). Pragmatism refers to making decisions on how research should be conducted based on the research aims or objectives (Ormston et al., 2014). As this study aims to merely describe caretakers' experiences whilst remote working to find areas where organisations and healthcare workers could assist these employees, this philosophical stance is deemed adequate.

\section{Researcher characteristics and reflexivity}

According to O'Brien et al. (2014) researcher characteristics such as personal attributes, qualifications, participant relationship, presuppositions and research method, can influence the research and should be reflected on by the researcher. Thus, the following researcher characteristics should be noted by the reader when considering the results of this study. The researcher is a white female with a PhD in Psychology in her late twenties, who performed this study as 
part of her post-doctoral fellowship research for a South African University. A researcher-participant relationship was followed throughout this research where the researcher aimed for ethical research behaviour and reporting of participant experiences. This relationship was initiated when an invitation with a link to the online questionnaire was posted on two large social media sites. Participants who chose to take part in the study were anonymised by the online data collection system Typeform.com. Participants had the opportunity to contact the researcher if they had questions regarding the online questionnaire, however, no contact was initiated. Thus, no direct interaction took place between the researcher and the participants during the research process. From a personal perspective, the researcher shared three characteristics with the participants. Firstly, the researcher is a South African citizen who lived in South Africa during the 2020 lockdown period. Secondly, the researcher is also a white female, making her part of the largest gender group that took part in this study. Lastly, the researcher has a PhD and forms part of the education level group of participants named "PhD".

Based on the researcher's community values of a traditional household structure and the read literature in preparation for this study, it was possible that there was the presupposition that women would be the primary caretakers during the COVID-19 lockdown. However, a co-coder whose community and household background differs significantly from the researcher by being modern and with an open family structure, was used to combat potential bias. Based on the lack of insight into the chosen topic, a qualitative method was chosen to perform this study. The researcher's experience regarding this method consists of a Master's degree in research psychology conducted using a qualitative research method and $\mathrm{ahD}$ focused on the use of research methodology.

\section{Context}

This research was completed online by participants between 16 March 2021 and 17 April 2021. Thus, participants were instructed to complete the questionnaire in an environment comfortable to them, where they had online access. Employees from all sectors were able to participate in the study, making the organisational setting all sectors with remote working employees during the COVID-19 lockdown. To allow for persons from all organisations to take part in the study and to adhere to social distancing measures in South Africa, an online questionnaire was deemed appropriate.

\section{Sampling strategy}

The sampling strategy consisted of the purposive and snowball sampling methods. Purposive sampling is generally used when conducting qualitative descriptive research (Palinkas et al., 2015) and refers to selecting participants who know the specific research phenomenon (Ritchie et al., 2009). Additionally, snowball sampling typically consists of the researcher sending the questionnaire to one or two persons and identifying others with the same characteristics for further research (Maree \& Pietersen, 2016). For this study, participants who self-identified with the following characteristics completed the online questionnaire: South African employees that have remote worked full-time or part-time during the 2020 lockdown period whilst caring for one or more children. The researcher posted an invitation for potential participants on social media sites Facebook and LinkedIn. This invitation included an informed consent form that listed the required participant characteristics to take part in this study. Therefore, individuals who do not use these social media platforms or have access to the internet to complete the internet survey were excluded. The sample size was determined by data saturation which is indicated when further coding is not possible, the ability for new information has been achieved, and there is enough information to replicate the study (Fusch \& Ness, 2015).

\section{Ethical clearance}

This study received ethical clearance from the Economic and Management Sciences Research Ethics Committee (EMS-REC), North-West University, Potchefstroom Campus, South Africa (NWU-00018-21-A4) on February 26 2021. Participants were provided with informed consent forms before taking voluntary part in the study to describe the purpose, extent and data access of their participation.

\section{Entrée and establishing researcher roles}

The researcher was responsible for gaining ethical and scientific clearance to conduct the study and invite participants to participate. Furthermore, the researcher was also available to participants and answered any questions regarding the research. Lastly, the researcher's most important role was to describe the participants' experiences.

\section{Data collection methods}

Textual data were collected on the online survey platform typeform.com and extracted in a Microsoft Excel Worksheet format (Professional version 2016) for data analysis. This data has been stored on an online open access repository (Figshare), where anonymous outputs can be shared with other researchers. The researcher posted an invitation to the research on the identified social media platforms indicating aspects such as voluntary participation, the contact information of the researcher and the participants' right to withdraw their participation at any time. Participants who 
wished to complete the questionnaire clicked on the provided questionnaire link, which directed them to the informed consent form and questionnaire on typeform.com. Participants were only able to complete and submit the questionnaire after agreeing to the informed consent form by clicking the "Agree" button. Typeform.com sent the data to the researcher for content analysis. Data collection commenced on 16 March 2021 and ended 17 April 2021. Data analysis and co-coding was performed from 18 April 2021 to 1 May 2021. A report was compiled based on the findings from data analysis.

\section{Data collection instruments and technologies}

Online approaches are becoming popular for qualitative descriptive studies and offer researchers flexibility and ease of participation (Doyle et al., 2020). According to Eckerdal and Hagström (2017), qualitative questionnaires can be helpful in various research disciplines by providing rich material. The qualitative questionnaire used in this study consisted of semi-structured questions based on the research question and study objectives. Semi-structured questions define the line of inquiry (Nieuwenhuis, 2007b), and for this study, five questions were included:

- Briefly describe your general experience of balancing work and childcare during the COVID-19 lockdown.

- Describe the assistance you had (if any) in balancing working from home and childcare?

- What organisational or personal resources have you used to balance working from home and child care during the COVID-19 lockdown?

- Where did you work best whilst working from home? (Describe the environment and circumstances)

- How could your organisation have assisted you in balancing remote work and childcare?

Units of study

The final sample consisted of 21 participants (four male; 18 female), with the youngest participant being 25 and the eldest being 59 (mean $=39$ years; mode $=30,34,36$ ). The sample consisted of White/Caucasian participants caring for a mean of two children. The specific sample characteristics are listed in Table 1.

Data processing

Data were extracted in a Microsoft Excel Worksheet (Professional version 2016) from the online data collection platform: Typeform.com. that anonymised participants. Questions were presented as headings, and participant answers were compiled under each relevant heading. Participants received participant numbers based on the Excel Worksheet line number their answers were logged in. Data were coded in this Microsoft Excel Worksheet and kept secure on the researcher's password-protected laptop. Coding took place on the same worksheet as the participant answers for each question to provide an audit trail.

Data analysis

Analysis of qualitative descriptive studies is data-driven and does not consult pre-existing epistemological or philosophical perspectives (Lambert \& Lambert, 2012). Content analysis is commonly used for qualitative descriptive designs as it limits the interpretation of results from the researcher (Hesse-Biber \& Leavy, 2011). In accordance with the study aim, this content analysis was based on exploratory work and provided a simple report of common aspects mentioned by participants (Green \& Thorogood, 2004). Specifically, an inductive, text-driven (Krippendorf, 2013) content analysis was applied wherein the researcher searched for variation and similarities in the data to finally produce descriptive categories or themes (Graneheim et al., 2017). The frequency with which some codes occurred were also considered and described as per classical content analysis (Leech \& Onwuegbuzie, 2008). The straightforward description of the qualitative descriptive data is a crucial strength of this design as researchers can more easily agree on the findings when limited interpretation was applied (Kim et al., 2017). Four stages were followed for data analysis as indicated in Table 2 (Bengtsson, 2016):

\section{Techniques to enhance trustworthiness}

Trustworthiness allows readers to have confidence in what the researcher has written about a phenomenon (Stahl \& King, 2020). Various criteria exist on how to promote the trustworthiness of a study; for this research, the following four critical measures of Lincoln and Guba (1985) were employed: credibility, dependability, transferability and confirmability. Credibility refers to the extent that participants' experiences are represented through the researcher and can be recognised by other researchers and readers (Tobin \& Begley, 2004). The researcher promoted credibility through prolonged engagement with the data, frequent debriefing with her supervisor and a thick description of the phenomenon 
Table 1. Sample characteristics.

\begin{tabular}{|c|c|}
\hline Characteristic & $f$ \\
\hline \multicolumn{2}{|c|}{ Age/developmental stage of child } \\
\hline Infant/Toddler (0-3 years) & 8 \\
\hline Early childhood (3-6 years) & 9 \\
\hline Middle childhood (6-11 years) & 15 \\
\hline Adolescence (11-20 years) & 7 \\
\hline \multicolumn{2}{|l|}{ Employee education level } \\
\hline Degree (Graduate/Honours) & 8 \\
\hline Diploma & 5 \\
\hline High school & 5 \\
\hline Master's degree & 1 \\
\hline PhD & 3 \\
\hline \multicolumn{2}{|l|}{ Work hours } \\
\hline Full time & 7 \\
\hline Part time & 15 \\
\hline \multicolumn{2}{|l|}{ Employment } \\
\hline Administration & 9 \\
\hline Agriculture & 2 \\
\hline Clothing & 1 \\
\hline Consultation service & 2 \\
\hline Education & 5 \\
\hline Financial & 1 \\
\hline Graphic design & 1 \\
\hline Legal collections & 1 \\
\hline Psychology & 1 \\
\hline Retail & 1 \\
\hline
\end{tabular}

Table 2. Stages of content analysis.

\begin{tabular}{|l|l|}
\hline Stages & Application \\
\hline 1. Decontextualisation & Familiarisation with text, creation of meaning units and code list. \\
\hline 2. Recontextualisation & $\begin{array}{l}\text { Re-read text, determine if all relevant content have been considered and exclude } \\
\text { (distance) irrelevant content. }\end{array}$ \\
\hline 3. Categorisation & Condense meaning units and identify themes and categories. \\
\hline 4. Compilation & Manifest analysis and writing up. \\
\hline
\end{tabular}

(Nieuwenhuis, 2016). Dependability of research findings was ensured through creating an audit trail (Lincoln \& Guba, 1985) of the decision-making process by keeping a journal. This allows other researchers to see the decisions the researcher made in analysing the data (Nieuwenhuis, 2016b). The transferability of qualitative research does not refer to generalising findings to a broader context but rather to what extent readers can connect findings to their own experience and to what extent the participants reflect the study context (Lincol \& Guba, 1985). To achieve transferability, the researcher provided a detailed description of the South African lockdown context, participants who cared for children and remote worked during this time and a qualitative research approach. Additionally, participants were purposefully chosen to represent the phenomenon under study. Lastly, confirmability of the study shows the extent to which the study findings are shaped by the participants and not the researcher biases or motivations (Lincoln \& Guba, 1985). The researcher provided a reflection on her own characteristics to highlight possible biases, included quotes from participants to support findings and an audit trail of the research process and data analysis (Nieuwenhuis, 2016b). 


\section{Results}

Findings of participant experiences are presented through descriptions that exhibit themes and categories (Kim et al., 2017). Overall the qualitative findings derived from the content analysis showed that employees experienced remote working and providing childcare during the COVID-19 lockdown period as a strenuous task: it was "difficult" (P11), "... stressful" (P6), "very challenging" (P19) and "chaos" (P22) (Scholtz, 2021). Participants often followed their expression of its difficulty with information on balancing work and family life:

[I] $t$ was stressful. I could not fully give my attention to my work and my child simultaneously" (P6) and "A balancing act between school requirements and work requirements. Extra demands placed by both work and school on parents which results in work time shifts and working later in the evening and earlier in the mornings when surroundings are quiet" (P14).

Another participant described the experience as:

[I] $t$ is hard to balance work and childcare because the children need attention and household duties need to be completed, also the work isn't being done by someone else. It is a race against the clock to have happy and provided for kids and work completed by the end of the day. Mostly work has to be done after the kids go to bed (P8).

Only three participants described their general experience as positive stating that is was "easy" (P8) or "good" (P1; P18).

The role players that promoted or hindered balancing remote work and childcare during the COVID-19 lockdown

When balancing work and childcare at home, participants received assistance mostly from their partners. This helped employees to divide work and family responsibilities: "My wife and I took turns to manage different responsibilities" (P20), and devised schedules "Schedule between my spouse and myself" (P16). However, in some cases this assistance was limited: "My husband was there to assist, but only when he came home after work in the evening" (P9). Other family members also assisted in childcare to create opportunities for employees to complete their work such as "The older kids helped a lot with the smaller child. The live in grandparents was great assistance in balancing the house work and assisting the older children" (P15). The environment played a role for one participant as they "[live on] a farm, it was not a problem" (P8), whereas one employee received help from a community member, namely: "from [a] pastor" (P23) in balancing their work and family. Five participants did not receive any assistance.

The organisational or personal resources employees used in balancing their remote work and childcare during the COVID-19 lockdown

Employee resources consisted of people, technology, time and their houses. Specifically, employees utilised organisational resources such as technology through "[Microsoft $]$ Teams" $(\mathrm{P} 1)$, and "online organisation resources ... " (P3) in balancing remote work and childcare. Personal resources included "Homeschooling via internet" (P22), "... home internet ..." (P20), "TV and DVDs ..." (P2) for entertaining children whilst working. People were also seen as both an organisational and personal resource to achieve balance between remote work and childcare, for example: "Family and employees had to help" (P4) and "Personal resources include my husband being able to take 1 child with to his work so there were days I only had 1 toddler to look after" (P9), or “... grandparents to assist with child care when possible ..." (P14).

Time slots as they became available for employees to complete their work were also employed as a valuable resource. For example, Participant 14 indicated that they worked "from 19:00 to 00:00 when all was quiet and I could focus on my work" and Participant 19 worked "[i] $n$ the mornings, while toddlers slept and middle childhood child did home Montessori work, so that there was uninterrupted time to work quickly".

Home spaces available for work were used or created; specifically, participants listed private spaces such as "... [a] room where I closed the door" (P2), or a home office: “... turned our spare room into an office" where "... our son knew he mustn't disturb us" (P20). The shared home spaces were used to perform childcare responsibilities while working like in the case of Participant 6 "In our living room, where I could keep an eye on my child playing outside/inside" or the "[i] $n$ the lounge or dining room table when the childrens home work also needed attention" (P15).

Lastly, employees restructured aspects of their home or work life to fit with their unique remote work contexts. For example, Participant 19 applied a "... stricter routine for children, chores for children. Work done while children take 
naps and did homework" to change her home life to fit with her work requirements. Participant 10, on the other hand, changed her mode of work: "Area (especially outside if possible) where kids can be play around you" to fit with her home or family requirements.

\section{The role organisations can play in assisting employees with balancing remote work and childcare}

"They need to give more autonomy ..." (P20) was a key feature of improving remote work and childcare for the sampled employees. This need for autonomy was expressed through more than half of the participants that listed "Flexible hours" (P13), or "Workable timeframes and deadlines" (P11) as a way organisations can assist in balancing their work and family lives. One participant described how flexible work hours was granted by their organisation during the lockdown: "There was a deadline, but it didn't matter at what time or how I got the work done, as long as it was finished by the deadline" (P19). In addition to flexible work hours, employees indicated that meetings as a mode of organisational communication were at times unnecessary "To not waste my time with unnecessary meetings and trainings that can be communicated through email." (P14) and that "minimising meetings that can be emails" (P4). Lastly, those that were not allowed to work remotely full-time expressed a desire to do so: "Working from home" $(\mathrm{P})$ or having "Childcare at work" (P2). However, participants did acknowledge that full-time remote work was not always possible: "Depending on the organisation. Consulting require face time with clients and interaction with team members. Working in isolation is not always feasible. Companies should remain fluid and flexible however employees should remain loyal and focused" (P16).

\section{Conclusions/discussion}

This study aimed to explore the experiences of employees whilst remote working and providing childcare during the 2020 COVID-19 lockdown in South Africa. The descriptive qualitative design showed that this South African sample's experiences were similar to many other international samples in that employees struggled to juggle work and family life during lockdown (Qian \& Fuller, 2020). Employees did not report disliking remote working; on the contrary, those who could only remote work part-time expressed their desire to do so full time. However, the lack of control over how they conducted their remote work made it challenging in the midst of childcare responsibilities. To combat this difficulty, the participants depended on certain role players as well as organisational and personal resources.

Unsurprisingly, the most significant role players lived with participants (e.g. partners, live-in grandparents and older children), which may be due to social distancing restrictions. Partners were the most popular role players and provided assistance based on availability and on schedules devised by couples. Creating schedules to conduct work or care for children can promote remote work; however, the choice of who worked and who cared for children during the pandemic was reportedly still burdensome for couples (Qian \& Fuller, 2020). Additionally, a study conducted in November 2020 found that despite men's involvement in childcare during the pandemic, South African female employees still took on most childcare responsibilities (Casale \& Shephers, 2020), which was also found in this study. Some female participants either received no assistance, worked whilst caring for children, had to wait for their partners to become available (i.e. return from work) or worked at night when children were asleep. Globally, gender inequality at work was as expected based on research indicating that women were often those who could not work due to childcare and that women are often part of the in-person labour market, which was hard hit by the lockdown (Kochhar \& Barroso, 2020; Lemieux et al., 2020). This study contributes to research in those South African women who remained employed during the lockdown through remote working still took on the bulk of the childcare responsibilities.

To achieve a balance between work and childcare, employees used personal resources such as people and spaces. Specifically, there were employees that chose private versus shared spaces to conduct their remote work at home. Those who chose private spaces strengthened the barriers between work and family life by trying to keep these two aspects separate by, for example, informing children not to disturb them when they are in their home office. Alternatively, some of the employees actively diminished these barriers by combining childcare and work, such as working outside while children played or working while children completed their homework in shared spaces such as dining rooms. This finding concurs with other research; whereas some employees prefer a separation between work and non-work roles, others choose to blur these roles (Gonsalves, 2020). The type of workspace employees chose could, therefore, possibly be dependent on employee preference (Gonsalves, 2020). Additionally, participants in this study also add to literature that the type of work they had to complete influenced their chosen workspace as, for example, private spaces helped them to focus.

Furthermore, based on the experiences and work hours, most employees often did not seem to control their work schedules at home. They usually only had time to work when childcare responsibilities and meetings forced them to work. Work-family conflict has been found to influence involuntary variable work schedules and vice versa and has been linked to lowered job satisfaction, perceived stress, psychological distress and greater turnover intention (Kaduk et al., 2019). 
However, if remote working employees follow a variable work schedule that they choose, i.e. "temporal flexibility" (Gonsalves, 2020), they experienced higher work satisfaction (Kaduk et al., 2019). Temporal flexibility has many benefits, such as decreasing work/family role blurring and improved employee health (Moen et al., 2016). Additionally, having control over their schedules can improve employee remote work experiences whilst also promoting the benefits of remote working for both the employee and the organisation (Kaduk et al., 2019). Therefore, organisations and healthcare workers are faced with an opportunity to improve South African employees' remote working experiences and reap the benefits of this new mode of work through flexible work hours. Especially considering that parents are part of the group most willing to remote work (Bloom, 2014) and most of the current study sample of child caregivers highlighted the need for creating flexible work hours.

Employees also stated that management could focus on adapting their mode of communication through limiting meetings or changing meeting times to accommodate most employees where possible. Zoom meetings have been found to require more emotional effort and cognitive load than in-person meetings due to the absence of non-verbal cues and the need for increased eye contact and focus (Sander \& Bauman, 2020). Additionally, employees with children have the added anxiety of a child interrupting or walking in during meetings (Sander \& Bauman, 2020). However, online meetings are unavoidable in the new remote workplace and employers are encouraged to use alternative forms of communication such as detailed documents or phone calls (Sander \& Bauman, 2020) to create online meeting breaks for employees. Other research found turning off video when not speaking in meetings or employing other technologies such as virtual reality headsets can assist in Zoom fatigue (Reinach, 2020). In this sample specifically, employees preferred communication to be through email rather than online meetings. New standards of working together and communicating are called for to adapt to the post-COVID-19 workplace (Wiatr, 2021).

The boundaries between work and home are in normal circumstances porous, with one often creeping over to the other (Dunn \& McMinn, 2021). This research concludes that employees used resources such as people, time and spaces to repair or uphold the balance between work and family by re-establishing these boundaries or intertwining work and family life in the new and abnormal work circumstances brought on by COVID-19. For managers, it is clear that South African remote working employees who care for children require flexible work hours and variation in the modes of communication to promote balance and thus well-being in their new remote working lives. Healthcare workers on the other hand, are encouraged to use findings to conduct further research into how resources can be employed to promote work-family balance for new remote workers.

\section{Practical implications}

Highlighting the possible areas of assistance for remote workers is imperative as childcare experience whilst remote working can have long-lasting repercussions for gender equity (Qian \& Fuller, 2020). Fear for child safety and the lack of capacity in certain schools indicate that some parents will still be required to work remotely despite the opening of schools and businesses (Qian \& Fuller, 2020). Thus, organisations are encouraged to use the collected data to improve the remote working experiences of child caregivers, especially female employees, to prohibit growth in the gender gap.

\section{Limitations and recommendations}

This study was limited by a small heterogeneous sample, thus findings should be seen within the context of the included participants. Future studies should attempt to conduct studies with larger samples of participants from different contexts. The online qualitative nature of this study should also be considered, as there was limited opportunity to probe for further information through this method; however, as this is at a time of remote working in the pandemic, an online questionnaire was deemed appropriate. Despite the lack of probing, the researcher experienced the descriptive design to be easily applied to online data collection, and it is recommended to other qualitative researchers with similar research aims. Future researchers are also encouraged to conduct similar studies or more in-depth research to confirm findings from this study or employ quantitative studies to reach larger groups of participants on this topic.

\section{Data availability}

Underlying data

Figshare: Remote work and childcare dataset - Controlled.xlsx. https://doi.org/10.6084/m9.figshare.14545998 (Scholtz, 2021).

This project contains the following underlying data:

- Remote work and chilcare dataset - Controlled.xlsx (raw data file)

\section{Extended data}


Figshare: Remote work and childcare dataset - Controlled.xlsx. https://doi.org/10.6084/m9.figshare.14545998 (Scholtz, 2021).

This project contains the following extended data:

- Remote work and childcare Informed consent and questionnaire.pdf (participant consent and questionnaire forms)

Data are available under the terms of the Creative Commons Attribution 4.0 International license (CC-BY 4.0)

\section{References}

Anderson D, Kellihner C: Enforced remote working and the work-life interface during lockdown. Gender Management Int J. 2020; 35(7/8):

677-683.

Publisher Full Text

Baard N, Thomas A: Teleworking in South Africa: Employee benefits and challenges. South African J Human Resource Management/Suid Afrikaanse Tydskrif vir Menslikehulpbronbestuur. 2010; 8(1): 1-10.

Publisher Full Text

Baruch Y: Teleworking: benefits and pitfalls as perceived by professionals and managers. New Technology Work and Employment 2000; 15(1): 34-49.

Publisher Full Text

Bengtsson M: How to plan and perform a qualitative study using content analysis. NursingPlus Open. 2016; 2: 8-14.

Publisher Full Text

Bloom N: To raise productivity let more employees work from home. Harvard Business Rev. 2014

Reference Source

Bloom N: How working from home works out. Institute for Economic Policy Research (SIEPR). Policy Brief June, 1-9. 2020.

Reference Source

Bhumika B: Challenges for work-life balance during CovID-19 induced nationwide lockdown: exploring gender difference in emotional exhaustion in the Indian setting. Gender management. 2020; 35(7-8) 705-718.

Reference Source

Bradshaw C, Atkinson S, Doody O: Employing a qualitative description approach in health care research. Glob Qual Nurs Res. 2017; 4: 1-8. PubMed Abstract | Publisher Full Text | Free Full Text

Casale D, Posel D: Gender inequality and the CoviD-19 crisis: Evidence from a large national survey during South Africa's lockdown. Res Social Stratification Mobility. 2020; 71(100569), 1-5.

Publisher Full Text

Chafe R: The Value of Qualitative Description in Health Services and Policy Research. Healthc Policy. 2017; 12(3): 12-18.

PubMed Abstract | Free Full Text

Creswell J: Qualitative inquiry and research design: Choosing among five approaches. 4th ed: Sage; 2018.

Del Boca D, Oggero N, Profeta P, et al.: Women's Work, Housework and Childcare, before and during COVID-19. Rev Economics Household. Springer;2020; 18(4), 1001-1017.

Doyle L, McCabe C, Keogh B, et al.: An overview of the qualitative descriptive design within nursing research. J Res Nursing. 2020; 25(5), 443-455.

Publisher Full Text

Dunn DS, McMinn JG: The Work-Life Balance of Academic

Psychologists: Evidence and Anecdote. Canadian Psychology/Psychologie canadienne. 2021 Advance online publication; 1-9.

Publisher Full Text

Eckerdal JR, Hagström C: Qualitative questionnaires as a method for information studies research. Information Res. 2017; 22(1).

Reference Source

Egbe CO, Londani M, Parry CDH, et al.: Tobacco use and nicotine dependence among people living with HIV who drink heavily in South Africa: a cross-sectional baseline study. BMC Public Health. 2019; 19(1), 1684

PubMed Abstract | Publisher Full Text | Free Full Text
Egbe CO, Ngobese SP: COVID-19 lockdown and the tobacco product ban in South Africa. Tob Induc Dis. 2020; 18.

PubMed Abstract | Publisher Full Text | Free Full Text

Fusch PI, Ness LR: Are we there yet? Data saturation in qualitative research. Qualitative Report. 2015; 20: 1408-1416.

Reference Source

Graneheim UH, Lindgren BM, Lundman B: Methodological challenges in qualitative content analysis: A discussion paper. Nurse Educ Today.

2017; 56: 29-34.

PubMed Abstract | Publisher Full Text

Green J, Thorogood N: Analysing qualitative data. In: Silverman D (Ed.) Qualitative Methods for Health Research. Sage Publications; 2004; (pp.173-200).

Gonsalves L: From face time to flex time: The role of physical space in worker temporal flexibility. Administrative Science Quarterly. 2020; 65(4): 1058-1091.

Publisher Full Text

Hall K, Mokomane Z: The shape of children's families and households: A demographic overview. In: Hall K, Richter L, Mokomane Z, et al. (Eds.),

Children, Families and the State: Collaboration and Contestation.

South African Child Gauge 2018. Children's Institute, UCT; 2018;

(pp. 31-45).

Reference Source

Hedding DW, Greve M, Breetzke GD, et al.: COVID-19 and the academe in South Africa: Not business as usual. Commentary. 2020; 116(7/8).

Publisher Full Text

Hesse-Biber SN, Leavy P: The practice of qualitative research.2nd ed: Sage Publications; 2011.

Jones KW: Managing Critical Infrastructure during the COVID-19 Pandemic. Infrastructure. 2020; 60: 1-17.

Reference Source

Kaduk A, Genadek K, Kelly EL, et al.: Involuntary vs. voluntary flexible work: insights for scholars and stakeholders. Community, Work \& Family. 2019; 22(4): 412-442.

Publisher Full Text

Kim H, Sefcik JS, Bradway C: Characteristics of qualitative descriptive studies: A systematic review. Res Nurs Health. 2017; 40 23-42.

PubMed Abstract | Publisher Full Text | Free Full Text

Lambert VA, Lambert CE: Qualitative descriptive research: An acceptable design. Pacific Rim Int J Nursing Res. 2012; 16: 255-256. Reference Source

Leech NL, Onwuegbuzie AJ: Qualitative data analysis: A compendium of techniques and a framework for selection for school psychology research and beyond. School psychology quarterly. 2008; 23(4): 587.

Publisher Full Text

Limoncelli TA: Five non-obvious remote work techniques. Everything sysadmin. 2020: 1-10.

Reference Source

Lincoln YS, Guba EG: Naturalistic Inquiry. Sage Publications; 1985.

Lopez-Núčez MI, Díaz-Morales JF, Aparicio-García ME: Individual differences, personality, social, family and work variables on mental health during COVID-19 outbreak in Spain. Personality Individual

Differences. 2021; 172(110562): 1-6.

Publisher Full Text

Maree K, Pietersen J: Sampling. In: Maree K (Ed.), First steps in research. VanSchaik Publishers; 2016; (pp. 192-202). 
Moen P, Kelly EL, Fan W, et al.: Does a flexibility/support organisational initiative improve high-tech employees' well-being? Evidence from the work, family, and health network. Am Sociol Review. 2016; 81:

134-164.

Publisher Full Text

Neergaard MA, Olesen F, Andersen RS, et al.: Qualitative description - the poor cousin of health research? BMC Med Res Methodol. 2009; 9: 52. PubMed Abstract | Publisher Full Text | Free Full Text

Nieuwehuis J: Qualitative research design and data gathering techniques. In: Maree K (Ed.), First steps in research. Van Schaik Publishers; 2007; (pp. 81-93)

Nieuwenhuis J: Introducing qualitative research. In: Maree K (Ed.), First steps in research. Van Schaik Publishers; 2016a; (pp. 50-69).

Nieuwenhuis J: Analysing qualitative data. In: Maree K (Ed.), First steps in research. Van Schaik Publishers; 2016b; (pp. 104-130).

Oakman J, Kinsman N, Stuckey R, et al.: A rapid review of mental and physical health effects of working at home: how do we optimise health? BMC Public Health. 2020; 20: 1825.

Publisher Full Text

Odeku KO: The plight of women entrepeneurs during COVID-19 pandemic lockdown in South Africa. Gender Behav. 2020; 18(3):

16068-16074.

Reference Source

Ormston R, Spencer L, Barnard M, et al.: The foundations of qualitative research. In: Ritchie J, Lewis J, McNaughton NC, et al. (Eds.), Qualitative

Research Practice. A Guide for Social Science Students and Researchers. Sage Publications; 2014; (2nd ed., pp. 1-25)

Palinkas LA, Horwitz SM, Green CA, et al.: Purposeful sampling

for qualitative data collection and analysis in mixed

method implementation research. Adm Policy Ment Health. 2015; 42: 533-544.

PubMed Abstract | Publisher Full Text | Free Full Text

Putro SS, Riyanto S: How Asian Sandwich Generation Managing Stress in Telecommuting during Covid-19 Pandemic. Int J Scientific Res Engg Development. 2020; 3(3): 487-492.

Reference Source

Qian Y, Fuller S: COVID-19 and the gender employment

gap among parents of young children. Canadian public policy. 2020 46(S2): 89-101.

Publisher Full Text

Ritchie J, Lewis J, Elam G: Designing and selecting samples. In: Ritchie $R$ Lewis J (Eds.), Qualitative research practice: A guide for social science students and researchers. SAGE Publications; 2009; (pp. 77-85).

Sandelowski M: Whatever happened to qualitative description? Res Nurs Health. 2000; 23: 334-340.

PubMed Abstract | Publisher Full Text
Sandelowski M: What's in a name? Qualitative description revisited. Res Nurs Health. 2010; 33: 77-84.

PubMed Abstract | Publisher Full Text

Sander $L$, Bauman $\mathrm{O}: 5$ reasons why Zoom meetings are so exhausting.

Conversation. 2020; 5

Reference Source

Sarbu M: The role of telecommuting for work-family conflict among German employees. Res Transportation Economics. 2018; 70: 37-51.

Publisher Full Text

Scholtz S: Remote work and chilcare dataset - Controlled.xlsx. figshare. Dataset. 2021

Publisher Full Text

Sevilla A, Smith S: Baby steps: The Gender Division of childcare after COVID19. CEPR Discussion Paper No. 14804. 2020.

Reference Source

Shockley KM, Clark MA, Dodd $\mathrm{H}$, et al.: Work-family strategies during COVID-19: Examining gender dynamics among dual-earner couples with young children. J Appl Psychol. 2020; 106, 15-28.

PubMed Abstract | Publisher Full Text

Stahl NA, King JR: Expanding approaches for research: Understanding and using trustworthiness in qualitative research. J Developmental

Education. 2020; 44(1): 26-29.

Reference Source

Stiegler N, Bouchard J: South Africa: Challenges and successes of the COVID-19 lockdown South Africa: challenges and successes of containment linked to COVID-19. Ann Med Psychol (Paris) J. 2020; 178(7): 695-698.

PubMed Abstract | Publisher Full Text | Free Full Tex

Sullivan-Bolyai S, Bova C, Harper D: Developing and refining interventions in persons with health disparities: the use of qualitative description. Nurs Outlook. 2005; 53(3): 127-133.

PubMed Abstract | Publisher Full Text

Tobin GA, Begley CM: Methodological rigour within a qualitative framework. J Adv Nurs. 2004; 48: 388-396.

PubMed Abstract | Publisher Full Text

Tuyo D: The unexpected benefits of remote work. USA: The Union Times; 2020.

Wiatr A: Flexible working arrangements- current conditions and research directions. Business Management 1.

Reference Source

Watson R: HR firm shares ideas to support working parents. Grand Rapids Business J. 2020, August 21: 1-3.

Reference Source

Zakij: Harvard business review: Leadership \& managing people. Don't just lead your people through trauma. Help them grow. 2020.

Reference Source 


\section{Open Peer Review}

\section{Current Peer Review Status: ?}

\section{Version 1}

Reviewer Report 20 April 2023

https://doi.org/10.5256/f1000research.56982.r168534

(c) 2023 Sutarto A. This is an open access peer review report distributed under the terms of the Creative Commons Attribution License, which permits unrestricted use, distribution, and reproduction in any medium, provided the original work is properly cited.

\section{Auditya Purwandini Sutarto}

Universitas Qomaruddin Fakultas Teknik, Gresik, Jawa Timur, Indonesia

\section{GENERAL COMMENTS}

This is an interesting study that explores how employees balance their unprecedented remote work and childcare tasks amidst the COVID-19 pandemic in the South African context. As an exploratory study, the authors used a qualitative study design to answer some related issues. This study was conducted two years ago; hence, it is important to add implications for more current contexts. Besides, I have some queries to improve the quality of manuscript

\section{TITLE}

Given a limited sample and design of study, a term "exploratory" may be added in the title

\section{INTRODUCTION}

The author can replace the earlier work of Tavares (2017) with other references (more recent) relate to remote work amidst the pandemic.

A clear identification how this current study will address the gaps or contribute to the existing remote work of knowledge is required. It may be directed to South Africa or global context.

\section{METHOD}

How does the author deal with the representativeness of South African remote workers when all the participants are "White/Caucasian"?

It is necessary to include only relevant information to the readers which contribute to their understanding of your chosen methods. The paper could be streamlined, omitting, or reducing unnecessary explanations of basic procedures of the qualitative study unless they are unfamiliar to the readers.

\section{RESULTS}

The author should provide context for selected quotes. For example, explaining who the participants and their background. 
Since the sample size is relatively small, it is possible to make a table consisting detail characteristics of the participants, rather than merged into a summary (ID Participant, Age, \#of children \& age, education level, etc). This will help the authors contextualize their selected quotes.

The presentation of the main themes under each research question is less unclear.

\section{DISCUSSION}

“The descriptive qualitative design showed that this South African sample's experiences were similar to many other international samples in that employees struggled to juggle work and family life during lockdown (Qian \& Fuller, 2020)" >> More citations are needed.

Do you have any suggestions for the implications of this study beyond the pandemic, as currently COVID-19 would no longer be a public health emergency and most countries tend to re-shift into conventional (office) work arrangements.

It is necessary to put the conclusion in the end of text, as a separate section from the Discussion, summarizing key findings how the study's findings answer your research questions.

More discussion regarding sub-theme and final themes. The author may refer to the following works related to family or child care while remote work during the pandemic to enrich the discussion:

- Barriga Medina et al., $(2021)^{1}$

- Bernhardt, Recksiedler \& Linberg (2022) ${ }^{2}$

- Çoban $(2022)^{3}$

- Schieman, Badawy, Milkie \& Bierman (2021) 4

- Wang, Liu, Qian \& Parker (2020) ${ }^{5}$

\section{REFERENCES}

Many citations are missing in the reference list. Please re-check.

Matli (2020), Khwela-Mdluli and Beharry-Ramraj (2020), Muller \& Burden, 2020, (Sarbu, 2020), Choudhury (2020), (Oakman, 2020), O’Brien et al., (2014) , Nieuwenhuis, 2007b Lemieux et al., (2020), Krippendorf, (2013)

\section{PRESENTATION}

Proofread is needed.

\section{References}

1. Barriga Medina HR, Campoverde Aguirre R, Coello-Montecel D, Ochoa Pacheco P, et al.: The Influence of Work-Family Conflict on Burnout during the COVID-19 Pandemic: The Effect of Teleworking Overload.Int J Environ Res Public Health. 2021; 18 (19). PubMed Abstract | Publisher Full Text

2. Bernhardt J, Recksiedler C, Linberg A: Work from home and parenting: Examining the role of work-family conflict and gender during the COVID-19 pandemic.J Soc Issues. 2022. PubMed Abstract | Publisher Full Text

3. Çoban S: Gender and telework: Work and family experiences of teleworking professional, middle-class, married women with children during the Covid-19 pandemic in Turkey.Gend Work 
Organ. 2022; 29 (1): 241-255 PubMed Abstract | Publisher Full Text

4. Schieman S, Badawy P, A. Milkie M, Bierman A: Work-Life Conflict During the COVID-19 Pandemic. Socius: Sociological Research for a Dynamic World. 2021; 7. Publisher Full Text

5. Wang B, Liu Y, Qian J, Parker SK: Achieving Effective Remote Working During the COVID-19

Pandemic: A Work Design Perspective.Appl Psychol. 2021; 70 (1): 16-59 PubMed Abstract I

Publisher Full Text

Is the work clearly and accurately presented and does it cite the current literature?

Partly

Is the study design appropriate and is the work technically sound?

Partly

Are sufficient details of methods and analysis provided to allow replication by others? Partly

If applicable, is the statistical analysis and its interpretation appropriate?

Not applicable

Are all the source data underlying the results available to ensure full reproducibility? Yes

Are the conclusions drawn adequately supported by the results?

Partly

Competing Interests: No competing interests were disclosed.

Reviewer Expertise: Industrial or organizational psychology, ergonomics

I confirm that I have read this submission and believe that I have an appropriate level of expertise to confirm that it is of an acceptable scientific standard, however I have significant reservations, as outlined above. 
The benefits of publishing with F1000Research:

- Your article is published within days, with no editorial bias

- You can publish traditional articles, null/negative results, case reports, data notes and more

- The peer review process is transparent and collaborative

- Your article is indexed in PubMed after passing peer review

- Dedicated customer support at every stage

For pre-submission enquiries, contact research@f1000.com 